\title{
ANTIOXIDATIVE PROPERTIES OF BEE POLLEN EXTRACTS EXAMINED BY EPR SPECTROSCOPY
}

\author{
Anna Rzepecka-Stojko ${ }^{1}$, Barbara Pilawa ${ }^{2}$, \\ Pawel Ramos ${ }^{2}$, Jerzy Stojko ${ }^{3}$ \\ ${ }^{1}$ Department of Pharmaceutical Chemistry, ${ }^{2}$ Department of Biophysics, \\ ${ }^{3}$ Department of Hygiene, Bioanalysis and Environmental Studies \\ ${ }^{1,2,3}$ School of Pharmacy and Laboratory Medicine, Medical University of Silesia in Katowice, \\ ${ }^{1}$ Jagiellońska 4, ${ }^{2}$ Jedności 8, ${ }^{3}$ Kasztanowa 3A, 41-200 Sosnowiec, Poland, \\ e-mail: annastojko@sum.edu.pl
}

Received 16 October 2011; accepted 24 April 2012

$\mathrm{S} \mathrm{u} \mathrm{m} \mathrm{m} \mathrm{a} \mathrm{r} \mathrm{y}$

Bee pollen is a valuable and highly recognized source of exogenous antioxidants. The aim of these studies was to determine the antioxidant capacity of three types of bee pollen extracts: ethanol extracts of bee pollen, pepsin extracts of bee pollen and ethanol extracts of pepsin-digested bee pollen. Their antioxidant properties were determined with the use of electron paramagnetic resonance (EPR) and their ability to quench DPPH free radicals was estimated. The EPR results showed that ethanol extracts of pepsin-digested bee pollen (EEPP) had the highest antioxidative effect and the highest free radical DPPH scavenging potential. The pepsin extracts of bee pollen (PEP) had the weakest antioxidant capacity. The ability to quench DPPH free radicals was also the weakest one for this extract. An average antioxidative effect was recorded for ethanol extracts of bee pollen (EEP).

Keywords: bee pollen, antioxidants, free radicals, EPR spectroscopy.

\section{INTRODUCTION}

Much attention has recently been paid to natural antioxidants in our food. To a large extent, this is related to our modern lifestyle. Our life routines quite frequently leads to oxidative stress resulting in civilization diseases. Free radicals are formed in the body during normal metabolic processes, and they are deactivated by internal defense mechanisms (mainly by antioxidative enzymes). But it is impossible to neutralize a much higher level of reactive oxygen species (ROS) in a disturbed homeostasis. This is when a dietary supply of antioxidative substances can step in to improve the defense of living cells and their physiological functions (Campos et al., 2003).

Bee pollen is a valuable and highly recognized source of exogenous antioxidants. It is a vegetable product which is collected and partly processed by bees.
Bee pollen has a high nutritional value and biotic activity (Leja et al., 2007; Kroyer and Hegedus, 2001), and it is the source of numerous biologically active substances. The most important groups of chemical compounds in bee pollen are the following: proteins and amino acids, carbohydrates, lipids and fatty acids, phenols, enzymes, vitamins and bioelements (Szczęsna, 2006; Ceksteryte et al., 2008).

The biological activity of bee pollen is related to its high antioxidative potential due to the presence of polyphenols, including flavonoids. Antioxidative activity of these compounds involves preventing the formation of reactive oxygen species by inhibiting the enzymes which generate ROS, chelating and reducing the ions of the transitory metals (especially iron and copper), and neutralizing (sweeping) free radicals (Saric et al., 2009; GomezCaravaca et al., 2006; Carpes et al., 
2009). The results of studies conducted in many leading scientific centers indicate that it is possible to employ the analyzed active fractions in the prophylaxis of the diseases in which carcinogens, stressors, or external physical factors belong, to etiologic factors (LeBlanc et al., 2009; Baltrusaityte et al., 2007; Marghitas et al., 2009).

Taking into consideration the above described properties of bee pollen, the aim of the studies was to determine the antioxidant capacity of three types of bee pollen extracts, namely, ethanol extracts of bee pollen, pepsin extracts of bee pollen and ethanol extracts of pepsin-digested bee pollen. Their antioxidant properties were determined with the use of electron paramagnetic resonance (EPR) and their ability to quench DPPH free radicals was estimated.

\section{MATERIAL AND METHODS}

The study material was comprised of ground bee pollen collected in 2007 in the apiary called "BARC'" in Kamianna, Poland (Fig. 1). Three types of extracts were prepared from the bee pollen: ethanol extracts, enzymatic extracts obtained by pepsin digestion of bee pollen, and ethanol extracts obtained from the substrate of an enzymatic hydrolysis of bee pollen.

Preparation of the extracts bee pollen Ethanol extracts of bee pollen (EEP)

Ethanol extracts were prepared according to a slightly modified method of Almaraz-Abarca et al. (2007). The ethanol extract of bee pollen was prepared by weighing $20 \mathrm{~g}$ of ground bee pollen, to within an accuracy of $0.01 \mathrm{~g}$. The bee pollen sample was extracted 5 times with a $50 \%(\mathrm{v} / \mathrm{v})$ ethanol aqueous solution, in $200 \mathrm{~cm}^{3}$ portions, and shaken each time for $60 \mathrm{~min}$ at room temperature to macerate the sample. After each extraction, the sample was filtered under reduced pressure with the use of a water pump. The filtrate was collected, and the substrate was extracted again with another portion of ethanol. The obtained filtrate was centrifuged at $10000 \mathrm{rpm}$ for $10 \mathrm{~min}$. It was evaporated under reduced pressure in a rotary vacuum evaporator (UNIPAN-PRO 350P). The evaporated extract was dried in a laboratory incubator at $38^{\circ} \mathrm{C}$ to obtain a solid mass. The dry residue of extract was weighed and then dissolved in a $50 \%$ $(\mathrm{v} / \mathrm{v})$ ethanol aqueous solution to obtain the concentration of $2 \mathrm{mg} / \mathrm{cm}^{3}$. These extracts are further referred to as EEP.

\section{Pepsin extracts of bee pollen (PEP)}

Pepsin extract of bee pollen was prepared according to a slightly modified method described by Nagai et al. (2005).

An amount of $20 \mathrm{~g}$ of bee pollen was weighed. After this, the sample was mixed with distilled water acidified with concentrated HCL to $\mathrm{pH}=2$. The volume of distilled water was 5 times the volume of the sample. Pepsin was added to the sample to obtain a concentration of $1.0 \%$.

Next the sample was incubated at $37^{\circ} \mathrm{C}$ for 48 h. Hydrolysis was arrested by boiling

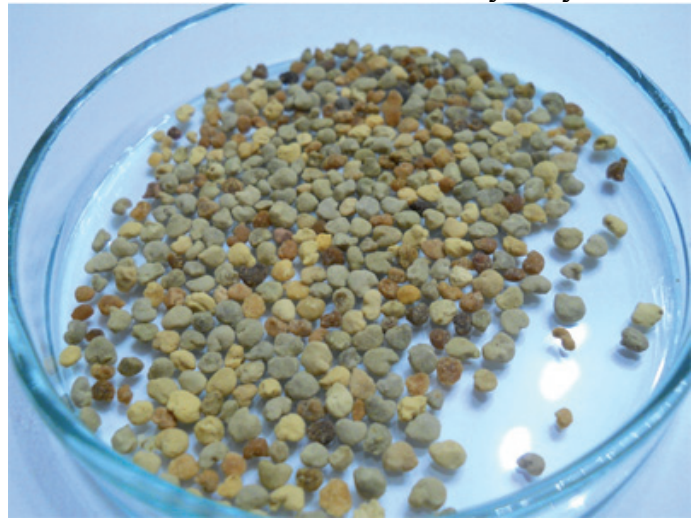

Fig. 1. Bee pollen. 
for $10 \mathrm{~min}$. The obtained enzymatic extract was filtered under reduced pressure with the use of a water pump. The filtrate was centrifuged at $10000 \mathrm{rpm}$ for $10 \mathrm{~min}$, and the supernatant was evaporated in a rotary vacuum evaporator (UNIPAN-PRO 350P). The obtained extract was dried in a laboratory incubator at $38^{\circ} \mathrm{C}$. A dry pepsin extract was weighed and then dissolved in acidified distilled water to obtain the concentration of $2 \mathrm{mg} / \mathrm{cm}^{3}$. This extract was used for further assays and referred to as PEP.

Ethanol extracts of pepsin-digested bee pollen (EEPP)

The obtained supernatant after pepsin extraction of bee pollen was extracted with $200 \mathrm{~cm}^{3} 50 \%(\mathrm{v} / \mathrm{v})$ of ethanol aqueous solution for $60 \mathrm{~min}$ at room temperature, and frequently shaken. The extract was filtered under reduced pressure, and then the filtrate was centrifuged at $10000 \mathrm{rpm}$ for $10 \mathrm{~min}$. The supernatant was evaporated under reduced pressure in a rotary vacuum evaporator (UNIPAN-PRO 350P). Next, the extract was dried in a laboratory incubator at $38^{\circ} \mathrm{C}$. The dry extract was dissolved in a $50 \%(\mathrm{v} / \mathrm{v})$ ethanol aqueous solution to obtain the concentration of $2 \mathrm{mg} / \mathrm{cm}^{3}$. This extract was used for further assays and referred to as EEPP.

\section{Preparation of the samples to EPR measurements}

The antioxidant capacity of three types of bee pollen extracts was determined with the use of electron paramagnetic resonance (EPR) spectroscopy. As a standard, DPPH (2,2-diphenyl-1-picrylhydrazyl) was used, and its chemical structure is shown in Fig. 2 (Grajka, 2007). The samples of ethanol extracts (EEP), pepsin extracts (PEP), and ethanol extracts of pepsin- digested bee pollen (EEPP), concentration of $2 \mathrm{mg} / \mathrm{cm}^{3}$, and DPPH concentration of $1 \times 10^{-4} \mathrm{M} / \mathrm{dm}^{3}$ were placed in thin-walled glass tubes. The inner diameter of the tubes was $1 \mathrm{~mm}$. The same volume of the samples was examined. The tubes with the samples were placed in a resonant cavity to measure their EPR spectra.

\section{EPR measurements}

A numerical recording of EPR spectra of bee pollen extracts, with DPPH as a spin label was done with the use of an X-band (9.3 GHz) EPR spectrometer, with a modulation of the magnetic field of $100 \mathrm{kHz}$ (Radiopan, Poznań, Poland). Linked to the spectrometer was the Rapid Scan Unit produced by Jagmar, Kraków, Poland, and a single EPR spectrum was measured at $10^{-4} \mathrm{~s}$. Microwave frequency was measured by a MCM101 recorder (Eprad, Poznań, Poland). The EPR spectra were measured at room temperature and they were recorded as the first derivative of absorption.

Low microwave power of $2.2 \mathrm{~mW}$ was applied during the measurements to avoid microwave saturation of the EPR spectra. The attenuation was then $15 \mathrm{~dB}$. Total microwave power produced by klystron is $70 \mathrm{~mW}$. The value of microwave power used during the experiment was obtained according to the following formula (W ertz and Bolton, 1986; Stankowski and Hilczer, 1994):

attenuation $(\mathrm{dB})=10 \lg \left(\mathrm{M}_{\mathrm{o}} / \mathrm{M}\right)$,

where: $\mathrm{M}_{\mathrm{o}}$ - total microwave power produced by klystron (70 $\mathrm{mW})$, $\mathrm{M}$ - microwave power used during the EPR spectrum measurement.

The EPR spectra were analysed by Labview sofware and the software by Jagmar. The following parameters of

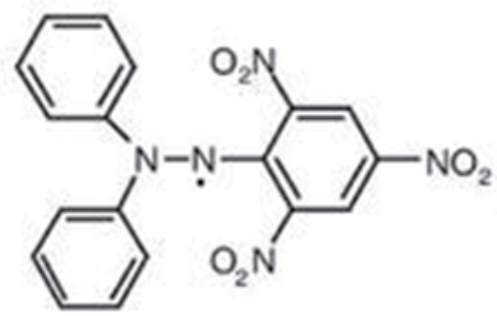

Fig. 2. Chemical structure of DPPH (Grajka, 2007). 
EPR spectra of DPPH were determined: amplitude (A), integral intensity (I), linewidth $\left(\Delta \mathrm{B}_{\mathrm{pp}}\right)$, and $\mathrm{g}$-factor. Integral intensity was obtained by double integration of the first-derivative of EPR spectrum. Amplitude and integral intensity increased when the amount of paramagnetic centers in the sample were increased (Wertz and Bolton, 1986; Kęcki, 1992). Linewidth depends on magnetic interactions in the tested structures. The g-factor tells the localization of an unpaired electron in the chemical structure of a sample (Wertz and Bolton, 1986; Kęcki, 1992). g-factor was calculated from resonance condition as:

$\mathrm{g}=\mathrm{hv} / \mu_{\mathrm{B}} \mathrm{B}_{\mathrm{r}}$,

where: ${ }^{2} h$ - Planck constant, $v$ - microwave frequency, $\mu_{\mathrm{B}}-$ Bohr magneton, $\mathrm{B}_{\mathrm{B}}$ - resonance magnetic field (Wertz and Bolton, 1986; Kęcki, 1992).
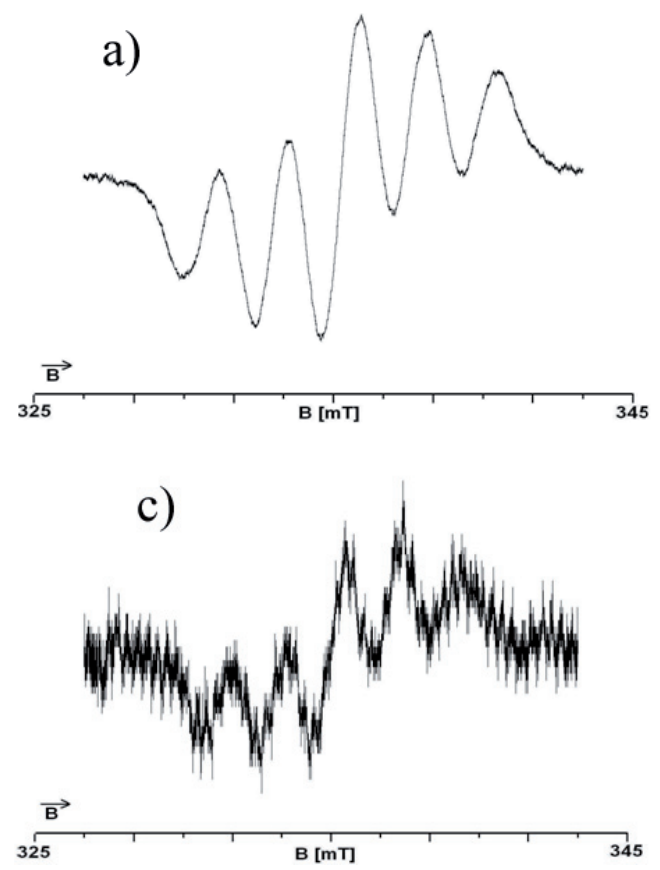

\section{RESULTS}

In Fig. 3, the EPR spectra of DPPH in ethanol extracts (EEP), pepsin extracts (PEP), and ethanol extracts of pepsindigested bee pollen (EEPP) and also EPR spectra of DPPH in ethanol as the reference, are presented. The g-factor for the studied samples was 2.0037. This g-value is characteristic for DPPH with an unpaired electron present in a nitrogen atom. The spectra differ in amplitude (A) and integral intensity (I). Amplitudes (A) of the individual extracts with DPPH as the standard are shown in Figure 4. Performed EPR studies have indicated that there are different antioxidant properties of the examined extracts of bee pollen.

The lowest amplitude (A) (Fig. 4) was obtained for EPR curves of DPPH present in the ethanol extract of pepsin-digested bee pollen (EEPP), which indicates the strongest antioxidant properties of this sample. Quenching of the free radical EPR

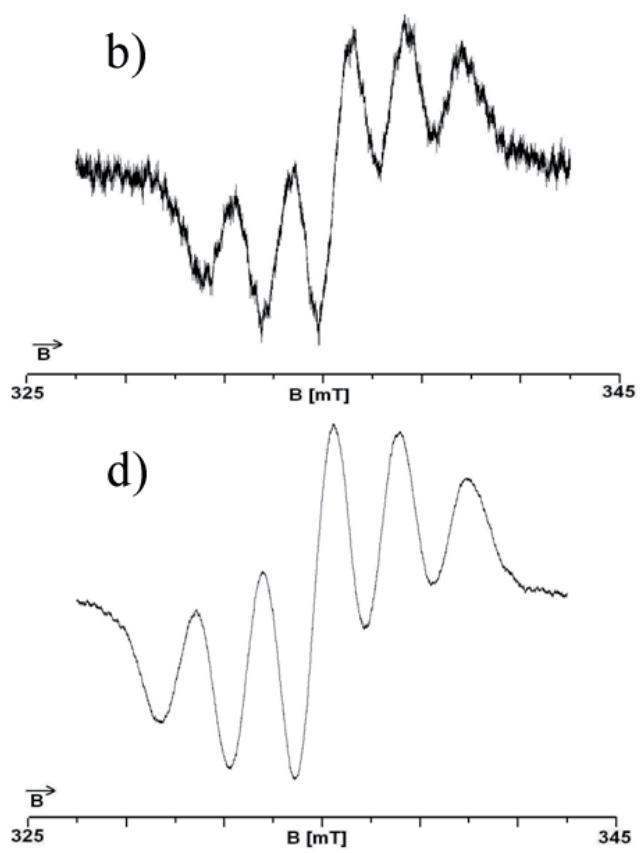

Fig. 3. EPR spectra of DPPH in:

a) Ethanol extracts of bee pollen (EEP);

b) Pepsin extracts of bee pollen (PEP);

c) Ethanol extracts of pepsin-digested bee pollen (EEPP);

d) DPPH in ethanol.

The spectra were measured with microwave power of $2.2 \mathrm{~mW}$. B is the induction of magnetic field. 


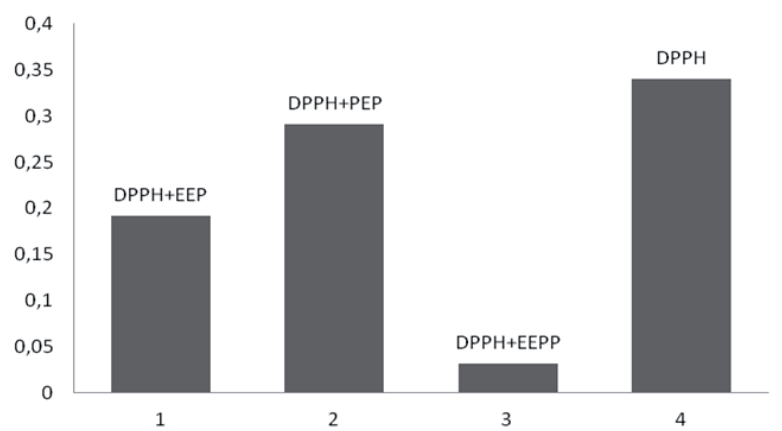

Fig. 4. Amplitudes of the EPR spectra of DPPH located in the studied: (1) ethanol extract EEP,

(2) pepsin extract PEP, (3) ethanol extract of pepsin-digested bee pollen EEPP,

(4) and DPPH in ethanol. EPR spectra were recorded 20 minutes after the addition of DPPH to the extract. Microwave power used during the measurement was $2.2 \mathrm{~mW}$.
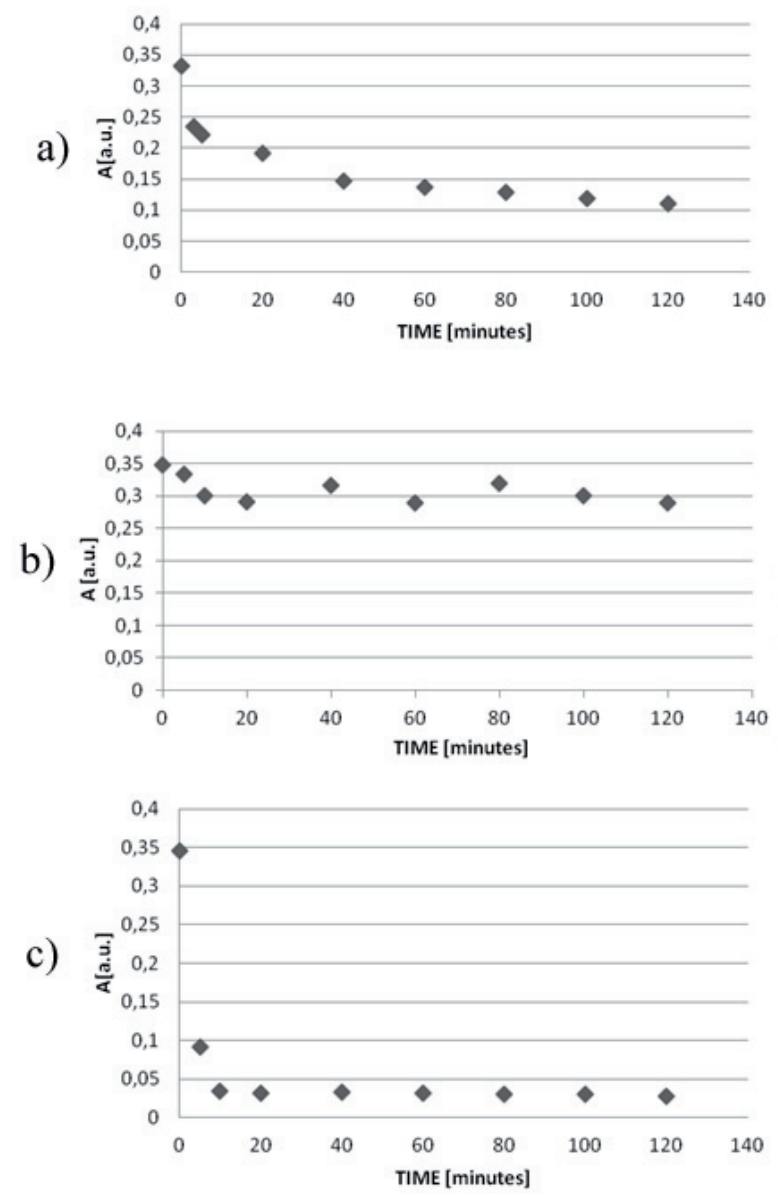

Fig. 5. Changes of amplitudes of the EPR spectra of DPPH located in the studied: a) ethanol extract (EEP);

b) pepsin extract (PEP);

c) ethanol extract of pepsin-digested bee pollen (EEPP).

Microwave power used during the measurement was $2.2 \mathrm{~mW}$. 
signal of DPPH by the above mentioned extract is the highest one. Interactions between this extract and free radicals of the standard sample reflect its antioxidant capacity. Relatively lower and similar amplitudes (A) (Fig. 4) characterize respectively, the ethanol extracts (EEP) and pepsin extracts (PEP) of bee pollen. These extracts have lesser antioxidant capacity.

The quenching kinetics of EPR spectrum of DPPH confirmed the correlations between antioxidant properties of the tested samples, which are presented in Figure 5. The kinetics of quenching of a spin label (DPPH) by tested extracts of bee pollen (Fig. 5) suggest the strongest reduction of free radicals by ethanol extracts of pepsindigested bee pollen (EEPP). A rapid decrease in the amplitude of EPR spectrum of DPPH spin label was observed after the addition of this extract (Fig. 5c). The changes in the EPR amplitude of DPPH after adding other studied extracts (PEP, EEP) are relatively slower (Fig. 5a,b). The slowest kinetics of EPR amplitude was obtained for PEP extracts (Fig. 5b).

\section{DISCUSSION}

Bee pollen is promoted as a health food. The pollen has a wide range of nutritional and therapeutic properties. Bee pollen is also used as a dietary supplement for humans. Reports have appeared in the literature regarding the antioxidant activity of bee collected pollen and the total phenolics (Campos, 2003).

Electron paramagnetic resonance spectroscopy is a helpful method for examining the natural antioxidants used in food products. Quenching of DPPH spin label, which was used in our experiment, is employed to evaluate antioxidant capacity of food and biological samples (Stankowski and Hilczer, 1994; Jóźwiak and Bartosz, 2005; Bartosz, 2005). Strong paramagnetism of DPPH plays an important role during the determination of antioxidant properties of tested samples.
The paramagnetic reference, i.e. $\mathrm{DPPH}$ containing unpaired electrons, is placed in the magnetic field produced by an electromagnet (Stankowski and Hilczer, 1994). The magnetic moments of unpaired electrons are oriented parallel or antiparallel to this magnetic field. These two orientations of unpaired electrons are responsible for the characteristics of two energy levels in the magnetic field. The electrons may be excited within these energy levels by external energy, which is the energy of microwaves in the electron paramagnetic resonance. This is a quantum effect, so the absorption of microwaves is possible only for the electromagnetic waves with the proper frequency. The microwave frequency should correspond to the difference between the energy of the excited electrons and the ground energy level of unpaired electrons.

The phenomenon of electron paramagnetic resonance is used in EPR spectroscopy to examine DPPH signals. The above mentioned method is based on the relation between the parameters of DPPH signals and the antioxidant properties of the tested samples. The quenching of paramagnetic centers in DPPH is correlated with an antioxidant effect of the studied extracts. The simple proportional relation between EPR spectrum of DPPH spin label and antioxidant properties of bee pollen extracts is the most important feature. The EPR method is the non-destructive one, which means the material can be tested several times. From both practical and economical points of view, it should be emphasized that only a small amount of a sample is necessary for the experimental procedures. Summing up, the electron paramagnetic resonance spectroscopy is an excellent example of a testing method for studying antioxidant properties.

Many reports on the relation between antioxidative effect of bee products and their polyphenol content have been published (LeBlanc et al., 2009; Carpes et al., 2009; Marghitas et al., 2009; Saric et al., 2009).

The EPR results showed that ethanol 
extracts of pepsin-digested bee pollen (EEPP) had the highest antioxidative effect and the highest free radical DPPH scavenging potential. The pepsin extracts of bee pollen (PEP) had the weakest antioxidant capacity. The ability to quench DPPH free radicals was also the weakest one for this extract. An average antioxidative effect was recorded for ethanol extracts of bee pollen (EEP).

The results of the electron paramagnetic resonance (EPR) study of the antioxidative effect of three types of bee pollen extracts correspond to the results for the determination of the polyphenol content in bee pollen extracts obtained with the same extraction methods (Rzepecka-Stojko et al., 2010).

When the study results of the antioxidative effect of bee pollen extracts obtained with three different methods were compared with their polyphenol content, it was concluded that the ethanol extract of pepsindigested bee pollen (EEPP), which had the highest antioxidative effect, contained the biggest amount of polyphenols - about $38 \mathrm{mg}$ GAE/g of extract (GAE - Gallic Acid Equivalent). An average polyphenol content in ethanol extracts of bee pollen (EEP) was $32.4 \mathrm{mg}$ GAE/g of extract. The pepsin extract of bee pollen (PEP), which had the weakest free radical DPPH scavenging potential, also contained the smallest amount of polyphenols $(6.67 \mathrm{mg}$ GAE/g of extract) (Rzepecka-Stojko et al., 2010).

In conclusion, the employed method of bee pollen extraction is of significant importance for the effectiveness of obtaining compounds which have antioxidative properties. Ethanol extraction of pepsin-digested bee pollen is the most effective extraction method for substances with an antioxidative effect. It may be assumed that pepsin and the acidic environment $(\mathrm{pH}=2)$ contribute to digestion of a cellular membrane of pollen grains in bee pollen, which increases the effectiveness of the ethanol solvent, and in consequence leads to higher extraction effectiveness of antioxidative substances.

\section{CONCLUSIONS}

EPR studies of bee pollen extracts indicate that:

1. The strongest antioxidant properties are characterized by ethanol extracts of pepsin-digested bee pollen (EEPP). Relatively lower and similar antioxidant properties are revealed by ethanol and pepsin extracts of bee pollen.

2. The quenching kinetics of amplitude of the DPPH EPR spectra in the presence of the studied bee pollen extracts have confirmed their antioxidant effects.

3. Antioxidant properties of the examined bee pollen extracts increase in the following order: pepsin extracts of bee pollen $(\mathrm{PEP})<$ ethanol extracts of bee pollen $($ EEP) $<$ ethanol extracts of pepsindigested bee pollen (EEPP).

4. Due to its antioxidant properties, bee pollen can become a dietary supplement, and above all, it can be added to functional food.

5. Electron paramagnetic resonance spectroscopy is a helpful examination method of natural antioxidants used in food products.

\section{ACKNOWLEDGEMENTS}

This study was supported by the Medical University of Silesia in Katowice, grant no. KNW-2-113/09.

\section{REFERENCES}

\begin{abstract}
Almaraz-Abarca N., Campos M. G., Avila-Reyes J. A., NaranjoJimenez N., Carrol H. J., GonzalezValdez L. S. (2007) - Antioxidant activity of polyphenolic extract of monofloral honeybeecollected pollen from mesquite (Prosopis juliflora, Leguminosae). J. Food Compos. Anal., 20(2): 119-124.
\end{abstract}

Baltrusaityte V., Venscutonis P. R., Ceksteryte V. (2007) - Radical scavenging activity of different floral origin honey and beebread phenolic exreacts. Food Chem., 101(2): 502-514.

Bartosz G. (2005) - Druga twarz tlenu. Wolne rodniki w przyrodzie. Wydawnictwo Naukowe $P W N$, Warszawa. 
Campos M. G., Webby R. F., Markham K. R., Mitchell K. A., Cuhna A. P. (2003)-Ageinduced diminution of free radical scavenging capacity in bee pollens and the contribution of constituent flavonoids. J. Agric. Food Chem., 51: 742-745.

Carpes S. T., Mourao G. B., Alencar S. M., Masson M. L. (2009) - Chemical composition and free radical scavenging activity of Apis mellifera bee pollen from Southern Brazil. Braz. J. Food Technol., 12(3): 220-229.

Ceksteryte V., Racys J., Kaskoniene V., Venskutonis P. R. (2008) - Fatty acid composition in beebread. Biologija, 54(4): 253-257.

Gomez-Caravaca A. M., GomezRomero M., Arraez-Roman D., SeguraCarretero A., Fernandez-Gutierrez A. (2006) - Advances In the analysis of phenolic compounds In products derived from bees. J. Pharm. Biomed. Anal., 41:1220-1234.

Grajka W. ed. (2007) - Przeciwutleniacze w żywności. Aspekty zdrowotne, technologiczne, molekularne i analityczne. Wydawnictwa Naukowo-Techniczne, Warszawa, pp. 538.

Jóźwiak Z., Bartosz G. (2005) - Biofizyka. Wybrane zagadnienia. Wydawnictwo Naukowe PWN, Warszawa, pp.

Kroyer G., Hegedus N. (2001) - Evaluation of bioactive properties of pollen extracts as functional dietary food supplement. Innov. Food Sci. Emerg.Technol., 2: 171-174.

Kęcki Z. (1992) - Podstawy spektroskopii molekularnej. Wydawnictwo Naukowe PWN, Warszawa, pp. 297-322.

LeBlanc B. W., Davis O. K., Boue S., DeLucca A., Debby T. (2009) Antioxidativ activity of Sonorant Desert bee pollen. Food Chem., 115: 1299-1305.

Leja M., Mareczek A., Wyżgolik G., Klepacz-Baniak J., Czekońska K. (2007) - Antioxidative properties of bee pollen in selected plant species. Food Chem., 100: 237-240.
Marghitas L. A., Stanciu O. G., Dezmirean D. S., Bobis O., Popescu O., Bogdanov S., Campos, M. G. (2009) - In vitro antioxidant capacity of honeybee-collected pollen of selected floral origin harvested from Romania. Food Chem., 115: 878-883.

Nagai T., Inoue R., Suzuki, N., Myoda, T., Nagashima T. (2005) Antioxidative ability in a linoleic acid oxidation system and scavenging abilities against active oxygen species of enzymatic hydrolysates from pollen Cistus ladaniferus. Int. J. Mol. Med., 15: 259-263.

Rzepecka-Stojko A., MaciejewskaPaszek I., Stec M., Kurzeja E., Kęska A., Pawłowska-Góral K. (2010) - The influence of extraction method on obtaining polyphenolic compounds from bee pollen. Farm. Przegl. Nauk., 1: 38-41.

Saric A., Balog T., Sobocanec S., Kusic B., Svarko V., Rusac G., Likic S., Bubalo D., Pinto B., Reali D., Maritti T. (2009) - Antioxidant effects of flavonoid from Croatian Cystus incanus L. rich bee pollen. Food Chem. Toxicol., 47: 547-554.

Stankowski J., Hilczer W. (1994) - Pierwszy krok ku radiospektroskopii rezonansów magnetycznych. OWN, Poznań, pp. 54-71.

Szczęsna T. (2006) - Protein content and amino acid composition of bee-collected pollen from selected botanical origins. J. Apic. Sci., 50(2): 81-90.

Wertz J. E., Bolton, J. R. (1986) Electron spin resonance. Elementary theory and practical applications. McGraw-Hill, New York, London, pp. 154-176. 


\title{
WŁAŚCIWOŚCI ANTYOKSYDACYJNE EKSTRAKTÓW Z PYLKU PSZCZELEGO BADANE METODĄ SPEKTROSKOPII EPR
}

\author{
Rzepecka-Stojko A., Pilawa B., \\ Ramos P., Stojko J. \\ S t r e s z c z e n i e
}

W ostatnim czasie dużo uwagi poświęca się substancjom o działaniu antyoksydacyjnym pochodzenia naturalnego. Cennym i uznanym źródłem egzogennych antyoksydantów jest pszczeli pyłek kwiatowy. W związku z powyższym, przedmiotem badań było oznaczenie aktywności antyoksydacyjnej trzech rodzajów ekstraktów z pyłku pszczelego: ekstraktu etanolowego pyłku pszczelego, ekstraktu pepsynowego pyłku pszczelego oraz ekstraktu etanolowego po uprzednim trawieniu enzymatycznym pepsyną pyłku pszczelego. Właściwości antyoksydacyjne oznaczono metodą elektronowego rezonansu paramagnetycznego (EPR) na podstawie zdolności redukcji wolnego rodnika DPPH. Najwyższą aktywnością antyoksydacyjną oznaczoną metodą EPR charakteryzował się ekstrakt etanolowy po uprzednim trawieniu enzymatycznym pepsyną pyłku pszczelego (EEPP). Dla tego rodzaju ekstraktu zdolność redukcji wolnego rodnika DPPH była najsilniejsza. Z kolei ekstrakt pepsynowy pyłku pszczelego (PEP) cechował się najniższą aktywnością antyoksydacyjną. Zdolność redukcji wolnego rodnika DPPH dla tego ekstraktu była najsłabsza. Pośrednią aktywność antyoksydacyjną spośród badanych ekstraktów wykazano dla ekstraktu etanolowego pyłku pszczelego (EEP).

Słowa kluczowe: pyłek pszczeli, aktywność antyoksydacyjna, wolne rodniki, spektroskopia EPR. 